\section{Calendar OF Meetings AND COURSES}

41st Annual Meeting of the American Society for Cell Biology

Washington, DC, USA, December 8-12, 2001

Contact: WWW: www.ascb.org

Following is a list of microscopy-related meetings and courses. The editors would greatly appreciate input to this list via the electronic submission form found in the MSA World Wide Web page at http:// www.msa.microscopy.com/. We will gladly add hypertext links to the notice on the Web and insert a listing of the meeting in the next issue of the Journal. Send comments and questions to JoAn Hudson, hjoan@clemson.edu or Nestor Zaluzec, zaluzec@aaem.amc.anl.gov. Please furnish the following minimum information (any additional information provided will be edited as required and printed on a spaceavailable basis):

-Meeting name

-Meeting dates

-Meeting topic or short description

-Meeting sponsor (society/organization/ university)

-Contact person

- Full postal address

-Telephone number

-Fax number

-E-mail address

-URL to a World Wide Web information page if available

\section{Meetings and Courses in 2001}

Workshop on Quantitative Image Analysis

Raleigh, North Carolina, USA, October 30-November 11, 2001

Sponsor: North Carolina State University Contact: WWW: www.ncsu.edu/cpe

30th Annual Meeting of the Society for Neuroscience

San Diego, California, USA, November 1015,2001

Contact: WWW: http://www.sfn.org
Meetings and Courses in 2002

Annual Meeting of the American Microscopical Society

Anaheim, California, USA, January 6-10, 2002

Sponsor: The American Microscopical Society (AMS)

Contact: SICB Business Office. Tel.: 800955-1236 or 312-527-6697; Fax: 703-7902672; E-mail: sicb@BurkInc.com or AMS Program Officer (Dr. John C. Clamp). Tel.: 919-560-6395; Fax: 919-530-7773; E-mail: jclamp@wpo.uccu.edu; WWW: http:// www.umesci.maine.edu/ams/symposia. htm

The American Microscopical Society (AMS) holds its annual meetings jointly with meetings of the Society for Integrative and Comparative Biology (SICB, formerly American Society of Zoologists) and The Crustacean Society.

\section{PITTCON 2002}

New Orleans, Louisiana, USA, March 1722, 2002

Contact: The Pittsburgh Conference, 300 burgh, PA 15235-5503, USA. Tel.: (412) 825-3220 or 1-800-825-3221; Fax: (412) 825-3224; E-mail: expo@pittcon.org; WWW: http://www.pittcon.org

\section{Microscopy \& Microanalysis 2002}

Quebec City, Quebec, Canada, August 4-8, 2002 Penn Center Boulevard, Suite 332, Pitts-
Sponsor: Microscopy Society of America (MSA), Microbeam Analysis Society (MAS), and the Microscopical Society of Canada (MSC)

Contact: Mary Beth Rebedeau, The Rebedeau Group, 7000 W. Southwest Hwy., Chicago Ridge, IL 60415, USA. Tel.: (708) 361-6000; Fax: (708) 361-6166; E-mail: msa@tradeshownet.com; WWW: http:// www.msa.microscopy.com/

This is the 60th Annual Meeting of the Microscopy Society of America, the 36th Annual Meeting of the Microbeam Analysis Society, and the 29th Annual Meeting of the Microscopical Society of Canada. Besides a diverse scientific program covering microscopy, it includes an extensive exhibit of instrumentation and support equipment.

The XVth International Congress on Electron Microscopy

Durban, South Africa, September 1-6, 2002

Sponsor: The Microscopy Society of Southern Africa under the auspices of the International Federation of Societies for Electron Microscopy (IFSEM)

Contact: Robin Cross, Electron Microscopy Unit, Rhodes University, Grahamstown 6140, South Africa. Tel: +27 46603 8168; Fax: +27 46622 4377; E-mail: eurc@ giraffe.ru.ac.za; WWW: http://www.ru. ac.za/affiliates/emu/icem2002.htm

\section{Meetings and Courses in 2003}

\section{PITTCON 2003}

Orlando, Florida, USA, March 9-14, 2003 Contact: The Pittsburgh Conference, 300 Penn Center Boulevard, Suite 332, Pittsburgh, PA 15235-5503, USA. Tel.: (412) 825-3220 or 1-800-825-3221; Fax: (412) 825-3224; E-mail: expo@pittcon.org; WWW: http://www.pittcon.org

(continued on page 548) 
Microscopy \& Microanalysis 2003

San Antonio, Texas, USA, August 3-7, 2003

Sponsor: Microscopy Society of America (MSA) and the Microbeam Analysis Society (MAS)

Contact: Mary Beth Rebedeau, The Rebedeau Group, 7000 W. Southwest Hwy., Chicago Ridge, IL 60415, USA. Tel.: (708) 361-6000; Fax: (708) 361-6166; E-mail: msa@tradeshownet.com; WWW: http:// www.msa.microscopy.com/

This is the 61st Annual Meeting of the Microscopy Society of America and the 37th Annual Meeting of the Microbeam Analysis Society. Besides a diverse scientific program covering microscopy, it includes an extensive exhibit of instrumentation and support equipment.

\section{Scanning 2003}

San Diego, CA, USA, Dates to be announced

Contact: Mary K. Sullivan. Tel.: (201) 8181010; Fax: (201) 818-0086; E-mail: scanning@fams.org

\section{Meetings and Courses in 2004}

\section{PITTCON 2004}

Chicago, Illinois, USA, March 7-12, 2004

Contact: The Pittsburgh Conference, 300 Penn Center Boulevard, Suite 332, Pittsburgh, PA 15235-5503 USA. Tel.: (412) 825-3220 or 1-800-825-3221; Fax: (412) 825-3224; E-mail: expo@pittcon.org; WWW: http://www.pittcon.org

\section{Microscopy \& Microanalysis 2004}

Savannah, Georgia, USA, August 1-5, 2004 Sponsor: Microscopy Society of America (MSA) and the Microbeam Analysis Society (MAS)

Contact: Mary Beth Rebedeau, The Rebedeau Group, 7000 W. Southwest Hwy., Chicago Ridge, IL 60415, USA. Tel.: (708) 361-6000; Fax: (708) 361-6166; E-mail: msa@tradeshownet.com; WWW: http:// www.msa.microscopy.com/

This is the 62nd Annual Meeting of the Microscopy Society of America and the 38th Annual Meeting of the Microbeam
Analysis Society. Besides a diverse scientific program covering microscopy, it includes an extensive exhibit of instrumentation and support equipment.

\section{Scanning 2004}

Washington, DC, USA, Dates to be announced

Contact: Mary K. Sullivan. Tel.: (201) 8181010; Fax: (201) 818-0086; E-mail: scanning@fams.org

\section{Microscopy \& Microanalysis 2005}

Honolulu, Hawaii, USA, July 31-August 4, 2005

Sponsor: Microscopy Society of America (MSA) and the Microbeam Analysis Society (MAS)

Contact: Mary Beth Rebedeau, The Rebedeau Group, 7000 W. Southwest Hwy., Chicago Ridge, IL 60415, USA. Tel.: (708) 361-6000; Fax: (708) 361-6166; E-mail: msa@tradeshownet.com; WWW: http:// www.msa.microscopy.com/

This is the 63rd Annual Meeting of the Microscopy Society of America and the 39th Annual Meeting of the Microbeam Analysis Society. Besides a diverse scientific program covering microscopy, it includes an extensive exhibit of instrumentation and support equipment.

\section{Meetings and Courses in 2005}

\section{Scanning 2005}

Monterey, CA, USA, Dates to be announced

Contact: Mary K. Sullivan. Tel.: (201) 8181010; Fax: (201) 818-0086; E-mail: scanning@fams.org

\section{Meetings and Courses in 2006}

\section{Microscopy \& Microanalysis 2006}

Chicago, Illinois, USA, August 6-10, 2006 Sponsor: Microscopy Society of America (MSA), Microbeam Analysis Society

(continued on page 555) 
(MAS), and the Microscopical Society of Canada (MSC)

Contact: Mary Beth Rebedeau, The Rebedeau Group, 7000 W. Southwest Hwy., Chicago Ridge, IL 60415, USA. Tel.: (708) 361-6000; Fax: (708) 361-6166; E-mail: msa@tradeshownet.com; WWW: http:// www.msa.microscopy.com/
This is the 64th Annual Meeting of the Microscopy Society of America, the 40th Annual Meeting of the Microbeam Analysis Society, and the 33rd Annual Meeting of the Microscopical Society of Canada. Besides a diverse scientific program covering microscopy, it includes an extensive exhibit of in- strumentation and support equipment.

\section{Scanning 2006}

New Orleans, LA, USA, Dates to be announced

Contact: Mary K. Sullivan, Tel.: (201) 8181010; Fax: (201) 818-0086; E-mail: scanning@fams.org 
Index to Advertisers

Diatome U.S.

Digital Instruments

Eastman Kodak Company

Electron Microscopy Sciences

Emispec Systems, Inc.

FEI Company

Gatan, Inc.

IXRF Systems, Inc.

JEOL USA, Inc.

Leica Microsystems

LEO Electron Microscopy

M.E. Taylor Engineering, Inc.

Micro Star Technologies

Olympus

Princeton Gamma-Tech

Ted Pella, Inc.

Thermo NORAN
459, 551

464

Cover 2

547, 548

463

Cover 3

546

550

552, Cover 4

549

461

551

555,560

466, 467

553

554

468 